Volume 12, Issue 2 (Summer 2020)

\title{
Seeing Outside the Box: Reexamining the Top of Samuel van Hoogstraten's London Perspective Box
}

Jun P. Nakamura

junn@umich.edu

Recommended Citation:

Jun P. Nakamura, "Seeing Outside the Box: Reexamining the Top of Samuel van Hoogstraten's London Perspective Box," Journal of Historians of Netherlandish Art 12:2 (Summer 2020) DOI: 10.5092/jhna.12.2.3

Available at https://jhna.org/articles/seeing-outside-the-box-reexamining-the-top-of-samuel-vanhoogstratens-london-perspective-box

Published by Historians of Netherlandish Art: https://hnanews.org/

Republication Guidelines: https://jhna.org/republication-guidelines/

Notes: This PDF is provided for reference purposes only and may not contain all the functionality or features of the original, online publication. This PDF provides paragraph numbers as well as page numbers for citation purposes.

ISSN: 1949-9833 


\section{Seeing Outside the Box: Reexamining the Top of Samuel van Hoogstraten's London Perspective Box}

Jun P. Nakamura

The anamorphosis decorating the top of Samuel van Hoogstraten's perspective box in London has long puzzled art historians; some prescribe a viewing position at the bottom right of the image, which only corrects some of its distortions, while others have dismissed it as a failed attempt. But rather than being a failure, the anamorphosis instead requires a corrective apparatus to mediate its viewing: either a concave lens or a viewing aperture originally mounted atop the box. This article argues for the necessity of such an apparatus and analyzes its implications in the context of the box's exterior decoration and ideas expounded in the artist's writings.

Samuel van Hoogstraten's perspective box in the National Gallery, London, is the finest example of six surviving seventeenth-century Dutch perspective boxes. ${ }^{1}$ Each box makes use of anamorphosis, a technique by which an image is skewed so that the optimal viewing perspective is at a severe oblique angle to the picture plane, in order to make the interior look like a large space when seen through a peephole. Van Hoogstraten's box is about two feet high and wide and three feet long, and it is open on one of the long sides in order to let in light (figs. 1-3). ${ }^{2}$ The inside is painted anamorphically to show a large domestic interior when seen through peepholes at either end of the box. There are multiple illusionistically painted doorkijken, or through-views, that offer glimpses into additional rooms and hallways connected to the central vestibule. Yet when viewed from the open side, the interior appears a jumble of incongruent perspectives awkwardly stretched and abutting one another.

2 Painted allegorical scenes decorate the box's exterior, which is quite different in character from the inside. The lateral panels feature allegorical representations of Seneca's three motivations for art: Amoris Causa, Glorioe Causa, and Lucri Causa (for the purposes of Love, Glory, and Money, respectively; figs. 4-6). ${ }^{3}$ On the top of the box is an anamorphically stretched image of a nude female figure-identified by scholars variously as Venus, Erato, or Danaë-lying in bed beside 


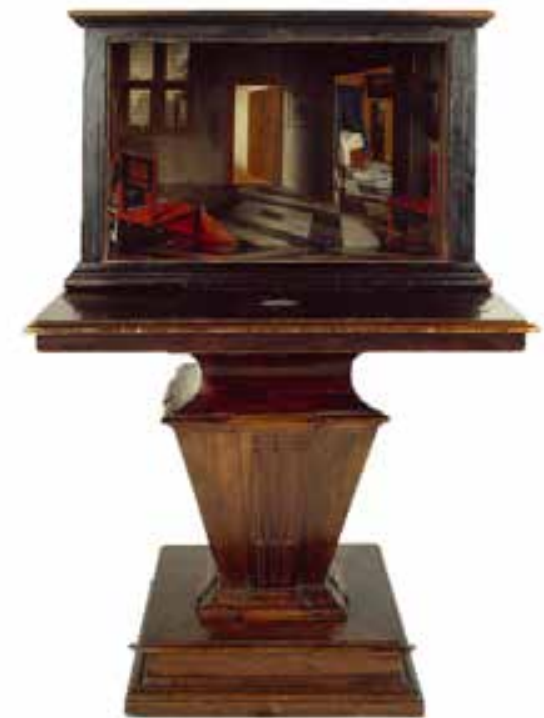

Fig. 1 Samuel van Hoogstraten, A Peepshow with Views of the Interior of a Dutch House, 1655-60, oil and egg on wood, $58 \times 88 \times 60.5 \mathrm{~cm}$, National Gallery, London, NG3832, presented by Sir Robert and Lady Witt through the National Art Collections Fund, 1924 (licensed under (reative Commons)
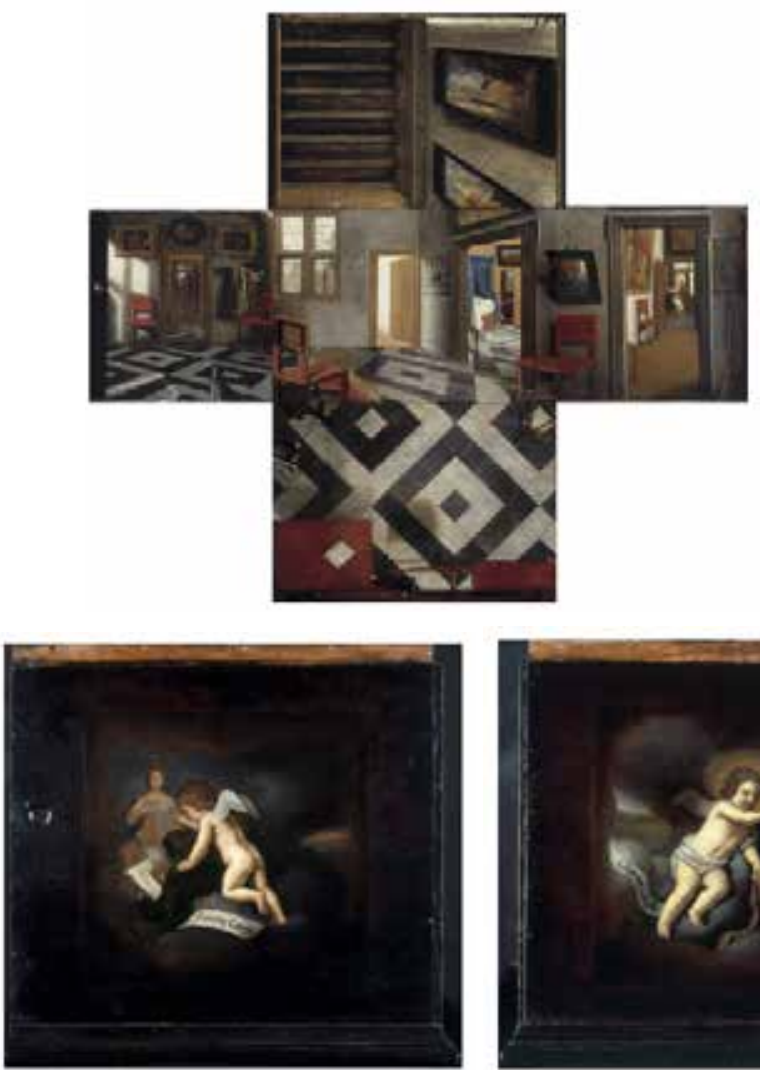

Fig. 4 Samuel van Hoogstraten, Amoris Causa, side panel of $A$ Peepshow with Views of the Interior of a Dutch House, $58 \mathrm{x}$ $60.5 \mathrm{~cm}$ (@ The National Gallery, London)

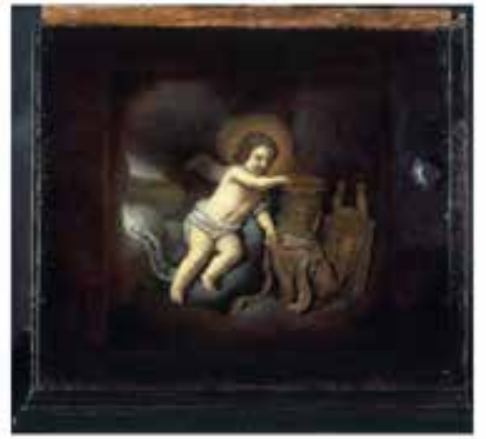

Fig. 5 Samuel van Hoogstraten, Gloriae Causa, side panel of $A$ Peepshow with Views of the Interior of a Dutch House, 58 × 60.5 $\mathrm{cm}$ (৫) The National Gallery, London)

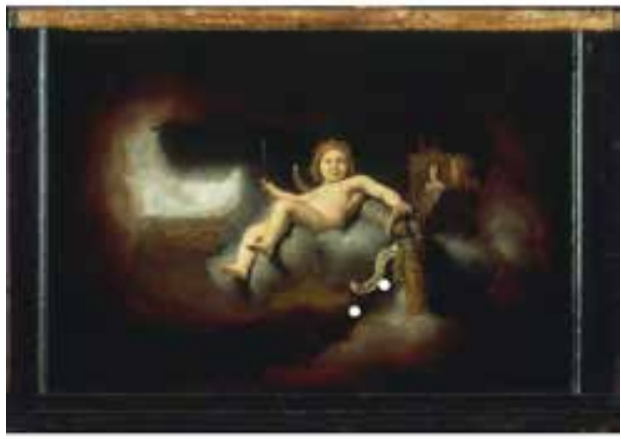

Fig. 6 Samuel van Hoogstraten, Lucri Causa, side panel of A Peepshow with Views of the Interior of a Dutch House, 58 $x 88 \mathrm{~cm}$ (@ The National Gallery, London) 
Cupid (fig. 7).

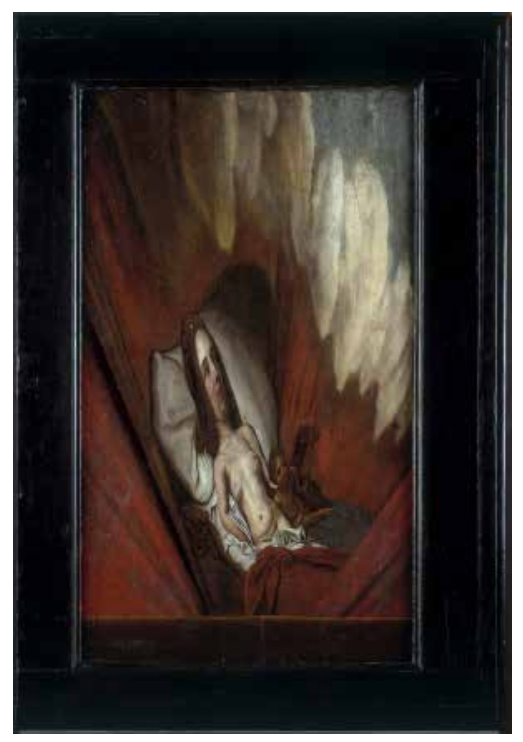

Fig. 7 Samuel van Hoogstraten, Venus/Danaë/Erato and Cupid, top panel of $A$ Peepshow with Views of the Interior of a Dutch

House, 88 x $60.5 \mathrm{~cm}$ (@ The National Gallery, London)

The exact nature of this anamorphosis has not been concretely established, although it has often been dismissed as unsuccessful due to difficulties in satisfactorily resolving the image. The present article will demonstrate that, far from being a failed attempt, the image on the lid employs a heretofore unrecognized variety of anamorphosis with significant implications regarding its viewing. I offer two possible correctives to the image atop the box, both of which posit the existence of a now-lost viewing apparatus that would have been attached to the box in its original form. ${ }^{4}$ I will explore the implications of these attachments, expanding upon Celeste Brusati's proposition that, via pictorial examples, the box demonstrates optical principles that van Hoogstraten would later explain in his treatise on art, the Inleyding tot de hooge schoole der schilderkonst: anders de zichtbaere werelt (Introduction to the Academy of Painting: or the Visible World), 1678.

4 The interior of the box, its program, and its construction have been discussed at length by Brusati, Thijs Weststeijn, Susan Koslow, David Bomford, Herman Colenbrander, and others. ${ }^{6}$ While Bomford has expertly explained the perspectival mechanics at play, interpretations of the interior of the box are still much contested; it has been postulated as a simple trick of the eye, a demonstration piece of optical experiments, a thematic meditation on love's generative capacity, a veiled brothel scene, and an emblematically dense marriage gift from van Hoogstraten to his wife. ${ }^{7}$ In this article, I leave aside the interpretive questions raised by the imagery of the box's domestic interior and focus primarily on the box's exterior, with particular attention to the lid.

5 The image atop the box has always been treated as a straightforward anamorphosis. Scholars who have considered the matter have postulated a viewing position "from a point somewhere at the

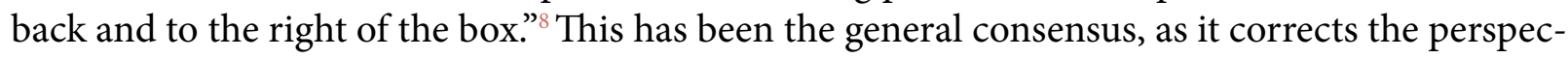
tive of the head of the female nude (fig. 8). Yet from this angle the head remains too large for the body, and the depicted space does not resolve into a coherent perspective. Only a few scholars have noted the strange proportions and angles that result from this supposed correction. Bomford describes it as: 


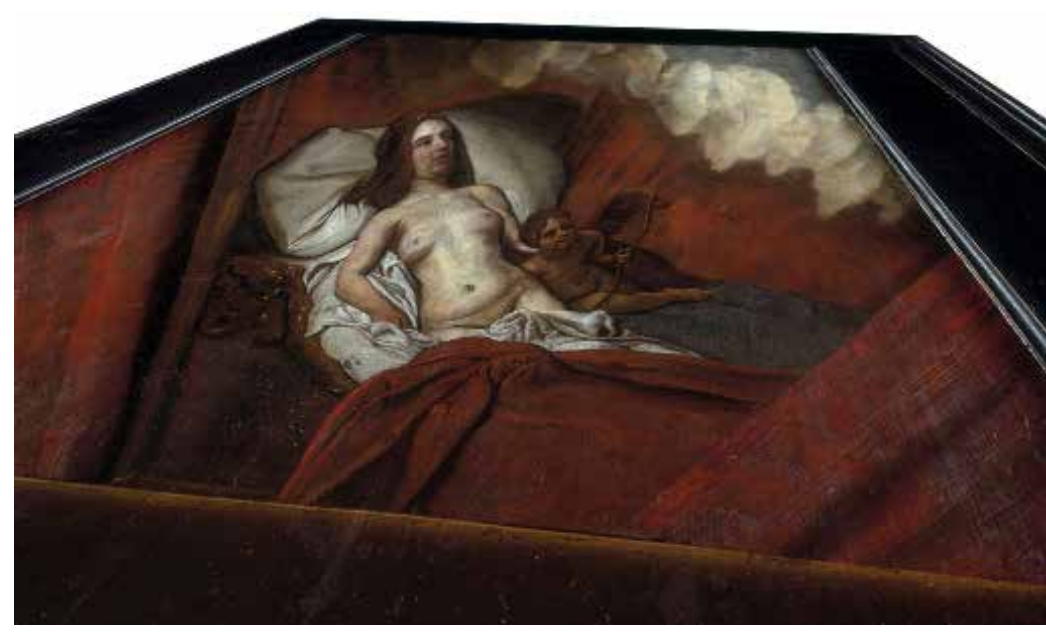

Fig. 8 Fig. 7 seen from viewpoint proposed by previous scholarship

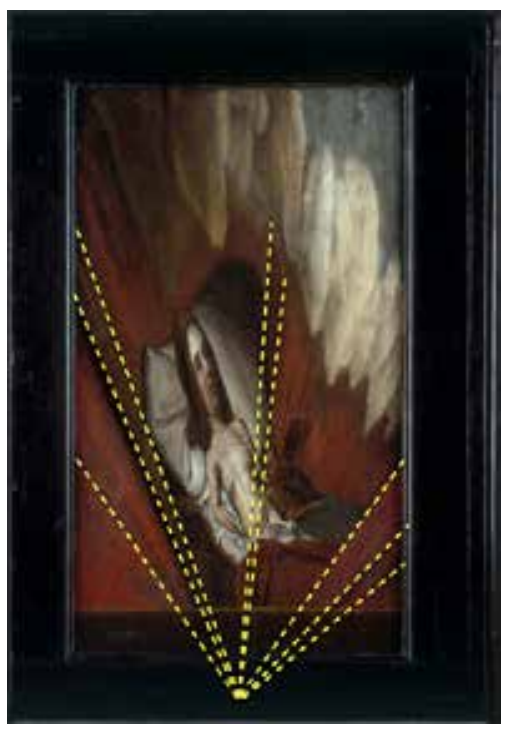

Fig. 9 Fig. 7 overlaid with lines drawn from vertical compositional elements

... a straightforward trapezoid anamorphic projection which is observed correctly by the observer approaching the right-hand end of the box. However, the centre of projection-the point from which it must be viewed-is off-centre and does not quite correspond with the viewer's approach to the peephole. It is not, in truth, an entirely successful anamorphic image: there seems to be no point from which it is convincingly corrected. ${ }^{9}$

Others have repeated the ideal viewing position from the bottom right of the image, though the resulting inconsistencies are rarely mentioned. Yet it seems implausible that van Hoogstraten would have failed to produce a very basic anamorphosis on the exterior of the box while having executed a singularly complex set of interlocking anamorphoses for the interior.

Bomford posits that the image was constructed empirically, due to a lack of drawn lines, and this may well be the case. ${ }^{10}$ But empirical construction does not preclude success, and lines within the image indicate an underlying perspectival structure. The depicted space contains bedposts and draped curtains which fall in lines that should appear more or less vertical once the anamorphosis is viewed from the intended position - but when viewed from the bottom right they form angles that are almost perpendicular at their extremes. The lines instead radiate from a point at the center of the image's lower edge (fig. 9), an area that falls just behind a brown strip about two inches wide that van Hoogstraten painted across the bottom of the panel. The strip, neither anamorphic nor illusionistic, has been entirely unremarked upon in scholarship on the box, but it is from a point just behind this brown strip that the image coheres.

I offer two possible modes of correction for the lid, both of which account for the presence of the brown strip. Both assume that van Hoogstraten's box originally supported a viewing apparatus in the center of the strip or immediately behind it, which would have mediated viewing of the lid. ${ }^{11}$ The first possibility is that van Hoogstraten used a large concave lens that would have formed the corrected image in its entirety before the viewer. The second possibility is simpler and parallels 
the peepholes already present on the box. If some sort of viewing aperture had been attached so that the viewer's vision was directed and limited, then the eye would have been fixed at a single point from which the anamorphosis was corrected and the field of vision limited to prevent perspectival dissonance. Through an aperture or lens, the brown strip is almost entirely hidden from view, visible only at the very margins, and whatever might be visible is made unobtrusive by its wooden coloring. ${ }^{12}$ In either case, the necessity of a viewing apparatus for the anamorphosis has significant implications for the interpretation of the box.

9 First, the lens. ${ }^{13}$ Numerous sources—including van Hoogstraten himself-recommend the use of lenses as an aid to artists. In Magia Naturalis (1558), Giambattista della Porta advises that by using a lens an artist might "describe compendiously" large and wide things:

[B]y opposition to a Concave Lenticular, those things that are in a great Plain are contracted into a small compass by it; so that a Painter that beholds it, may with little labour and skill, draw them all proportionable and exactly[.] ${ }^{14}$

In Book 7 of his Inleyding, van Hoogstraten advised painters to make use of lenses and the camera obscura, which could condense a larger scene to give a better sense of its general coloring and tonalities. ${ }^{15}$ The capacity of the lens to collapse wide views within a small frame was thus vital to its use as an artist's tool. A concave lens mounted at the center of the brown strip could likewise condense the painting atop the box, thereby demonstrating experimentally the capacities of the lens described textually by both van Hoogstraten and della Porta (figs. 10-13). ${ }^{16}$

11 Magia Naturalis and other period texts on optics further discuss how lenses might "make an image seem to hang in the air." ${ }^{17}$ Della Porta enumerates the various ways in which one can place lenses in front of objects such that their images appear to float before the viewer. ${ }^{18}$ When a concave lens is placed above and in front of the image atop the box, it produces a similar effect, but unlike della Porta's object reconstituted in a lens placed directly in front of it, van Hoogstraten's painting would be placed obliquely before the lens. The corrected image would then exist only within the lens, as if conjured from nothing. The lens's constitutive capacity is thus twofold, not only refiguring the anamorphosis in a comprehensible manner but also making the now-coherent arrangement of colors "float" in the lens before the viewer. This mounted lens would ideally have

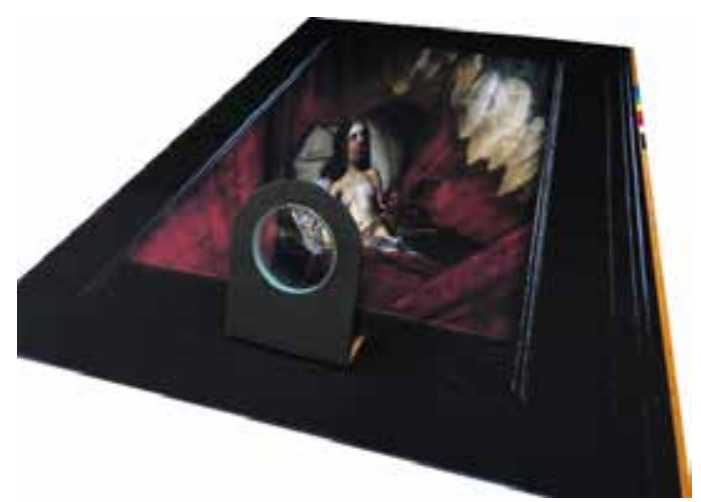

Fig. 10 Full-scale facsimile of fig. 7 with a $7.5 \mathrm{~cm}$ diameter biconcave lens with $20 \mathrm{~cm}$ focal length, mounted $9.5 \mathrm{~cm}$ above the image, angled slightly downward

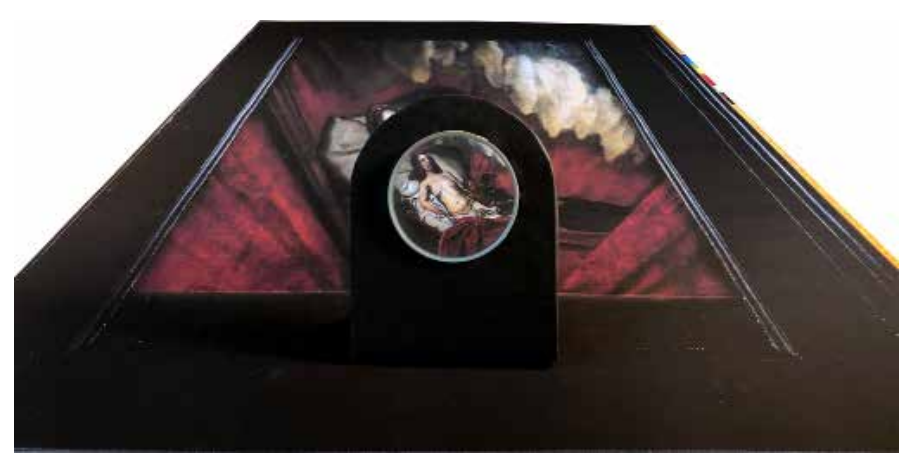

Fig. 11 Full-scale facsimile of fig. 7 with a $7.5 \mathrm{~cm}$ diameter biconcave lens with 20 $\mathrm{cm}$ focal length, mounted $9.5 \mathrm{~cm}$ above the image, angled slightly downward 


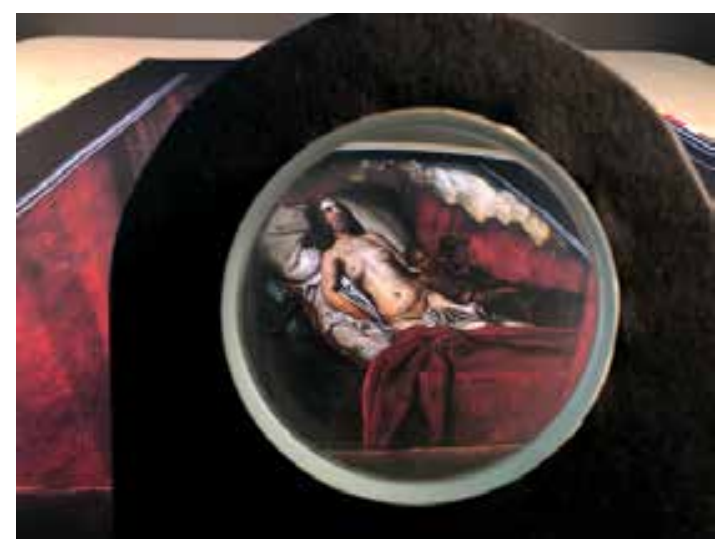

Fig. 12 Full-scale facsimile of fig. 7 as viewed through a $7.5 \mathrm{~cm}$ diameter biconcave lens with $20 \mathrm{~cm}$ focal length, placed $9.5 \mathrm{~cm}$ above the image, angled slightly downward

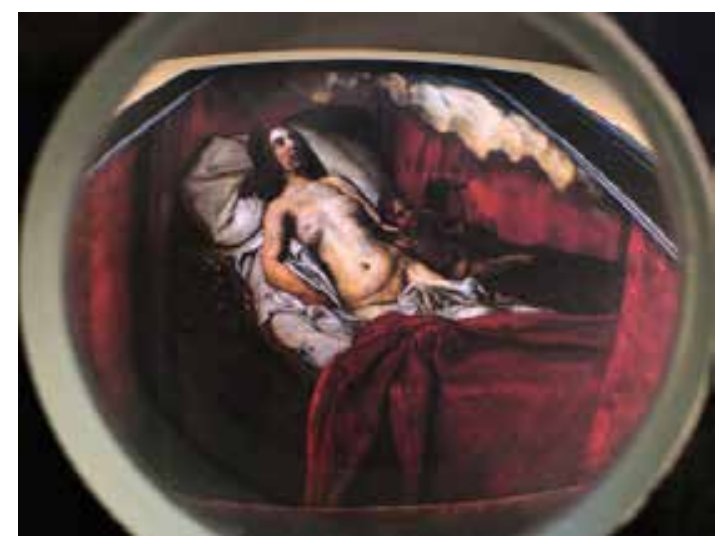

Fig. 13 Full-scale facsimile of fig. 7 as viewed through a $7.5 \mathrm{~cm}$ diameter biconcave lens with $20 \mathrm{~cm}$ focal length, placed $9.5 \mathrm{~cm}$ above the image, angled slightly downward

been a few inches in diameter so that one could view it from a distance. ${ }^{19}$

Kepler, Descartes, and other seventeenth-century natural philosophers emphasized the mechanical nature of the human eye, describing it as a dark chamber into which an image of the outside world is projected, via the biconvex lens of the crystalline. ${ }^{20}$ They conceptualized the eye as a miniature camera obscura and consequently noted its mechanical fallibility. ${ }^{21}$ Kepler notes that the act of vision is both subject to deception and deceptive in and of itself. ${ }^{22}$ Van Hoogstraten himself calls attention to the fallibility of sight in Book Seven, Chapter Seven of the Inleyding:

[T] here is nothing more easily tricked than sight. But I say that a painter, whose work it is to trick sight, should also have enough knowledge of the nature of things that he fundamentally understands by what means the eye is tricked. ${ }^{2}$

Brusati has argued that the interior of van Hoogstraten's box was an affirmation of this idea, in that it revealed "how the eye is deceived both by the painter's art and by the act of seeing itself." ${ }^{24}$ Through its deception, the views seen through the peepholes call attention to the fallibility of vision and the mechanical nature of sight.

14 In two articles on modern uses of anamorphoses in art, Daniel Collins notes how the anamorphic image offers the viewer an active role in the creation of the image and calls attention to the act of seeing. Collins calls the viewer of anamorphoses the "eccentric observer," or an observer "who literally stands apart and is self-aware of the process of seeing." ${ }^{25}$ This "stand[ing] apart from seeing" is even more literal in an anamorphosis corrected by a lens, because the point at which the image is resolved (i.e., in the lens) exists outside of the eye of the viewer. While Kepler and others explained the eye as lens in their writings on optics, van Hoogstraten demonstrated it experimentally. A lens mounted atop the box would have provided a visual experiment that the viewer could compare with the illusions provided through the peepholes on either side of the box. In the juxtaposition of peephole and lens, van Hoogstraten called attention to the mechanical nature of vision by showing that the eye situated before the peephole is subject to the same deception-and undergoes the same constitutive image-making process-as the lens atop the box. But unlike the peeping eye, which had to look around inside the box, the lens would form the image in its entire- 
ty so that the viewer could view it from a remove. Via lenticular proxy, they could see seeing.

One problem arises from a lens-based solution: the lines of the hanging curtains that should be straight and vertical become slightly curved in the lens, especially at the margins. Yet this does not eliminate the lens as a possibility; in his Inleyding van Hoogstraten states that due to our seeing in the round, straight lines often appear curved: "[A]s you can see standing before a building or a church, not only do both the ends of the walls but also the towers slope away from us, [becoming] foreshortened and diminished." ${ }^{26}$ Van Hoogstraten continues that it would be silly to represent such curves unless the intention was for the work to be seen "from very close up."

A second possible corrective avoids the distortions of the lens and coincides with this conception of a distorted work meant to be seen from "from very close up." Rather than a lens, Van Hoogstraten may have mounted a sort of peephole atop the box, replacing the lens with the eye itself. This could have been as simple as a mounted ring but would have functioned better if it blocked out the surrounding area so that the eye could not see around it (figs. 14-18, video online). By restricting the viewer's mobility and use of both eyes, a peephole limits the viewer to static monocular depth cues, most of which can be counterfeited on a flat surface. Furthermore, as vision is limited to a small portion of depicted space at any given time, the left-most part of the image does not require the same vanishing point as the right-most part. By creating different perspectives

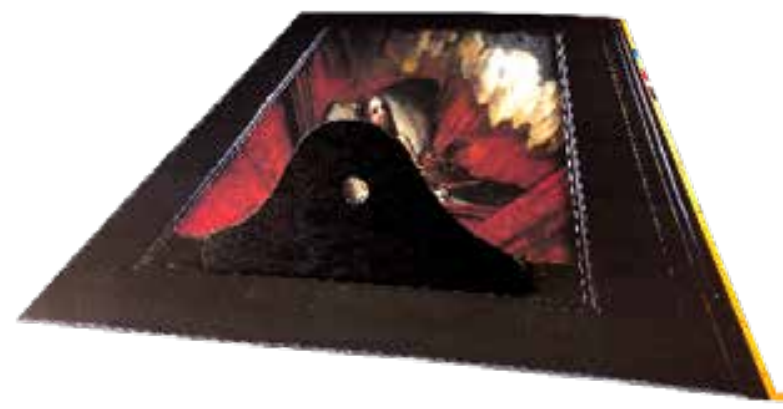

Fig. 14 Mock-up of an aperture/peephole mounted atop a full-scale facsimile of fig. 7

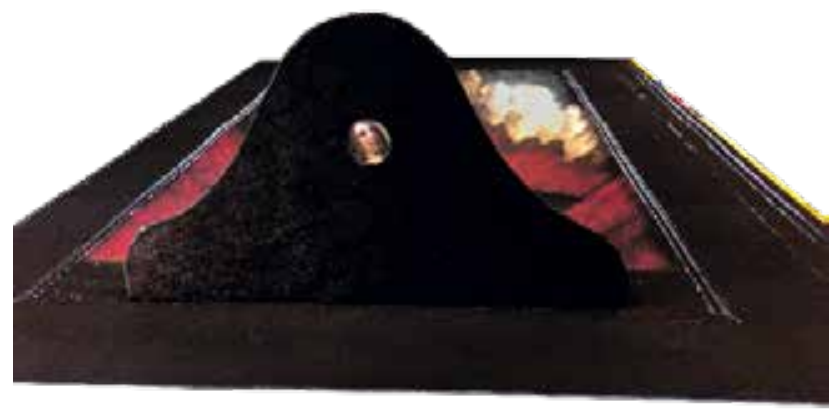

Fig. 15 Mock-up of an aperture/peephole mounted atop a full-scale facsimile of fig. 7

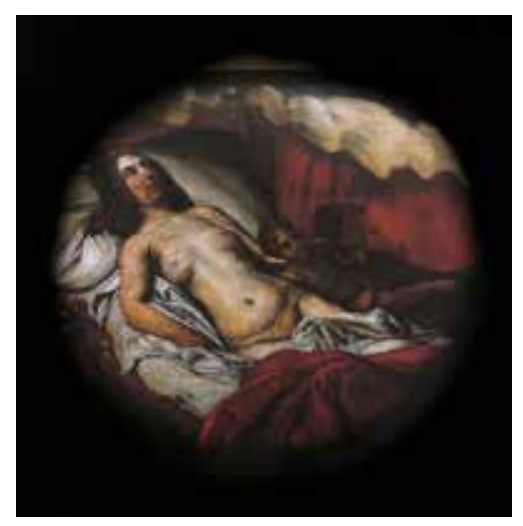

Fig. 16 Full-scale facsimile of fig. 7 as seen through an aperture/peephole of $2.5 \mathrm{~cm}$ diameter, placed $9.8 \mathrm{~cm}$ above the image

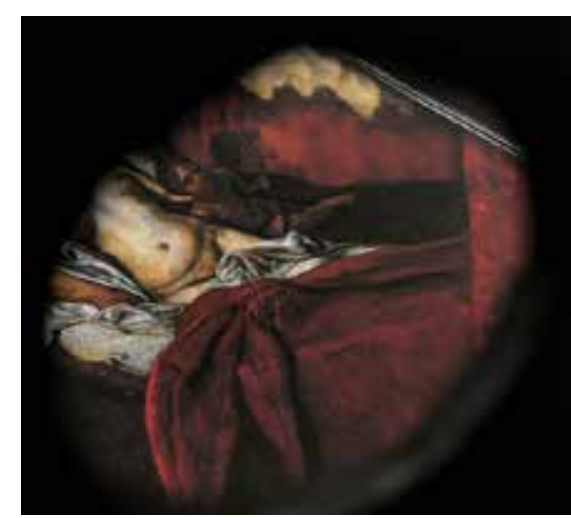

Fig. 17 Full-scale facsimile of fig. 7 as seen through an aperture/peephole of $2.5 \mathrm{~cm}$ diameter, placed $9.8 \mathrm{~cm}$ above the image

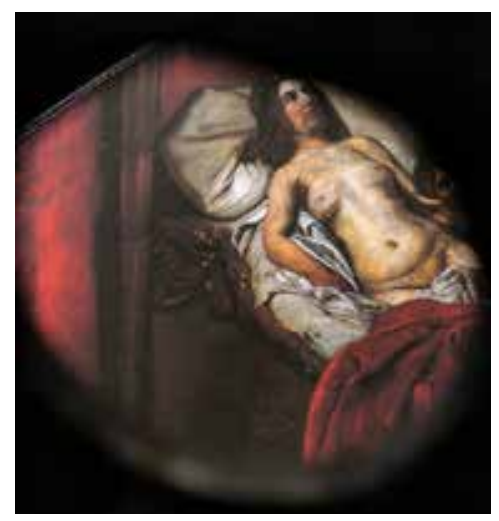

Fig. 18 Full-scale facsimile of fig. 7 as seen through an aperture/peephole of $2.5 \mathrm{~cm}$ diameter, placed $9.8 \mathrm{~cm}$ above the image 
that fan out radially from the aperture, van Hoogstraten could simulate the experience of looking around oneself at an image in the round, albeit through a peephole. As a viewer moves their eye from one side to the other, incongruous perspectives become resolved as an accumulation of aggregate views seen through an aperture.

A figure from Hans Vredeman de Vries's Perspective illustrates the idea of a mobile eye at the center of a changing perspective (fig. 19) ${ }^{27}$ Vredeman's diagram depicts multiple distance points that result from moving one's eye around a horizon, with a view marked every ninety degrees of the circular horizon. ${ }^{28}$ Citing Vredeman's diagram, Walter Liedtke has argued that Carel Fabritius's panoramic View in Delft was originally mounted on a curved support and displayed within a triangular perspective box (fig. 20). ${ }^{29}$ While Fabritius's view may have originally been curved in order to surround the eye of the viewer, van Hoogstraten's image is projected anamorphically so that it too surrounds the viewer. As a result, it has points of view that are meant to be seen from angles that vary by nearly ninety degrees from the left-most to the right-most. This is precisely why the concave lens works as another corrective: it collapses the expanded view around it into a smaller area, and it does so from the prescribed point of view at the center of the arc. The tacit principles behind this construction are stated in the Inleyding: "[W]e see around us with our eyes, and therefore no straight line can be drawn, which is at all points equally near to our eyes; but [we can draw] a curve, like the outline of a circle, of which the center is in our eye." ${ }^{30}$

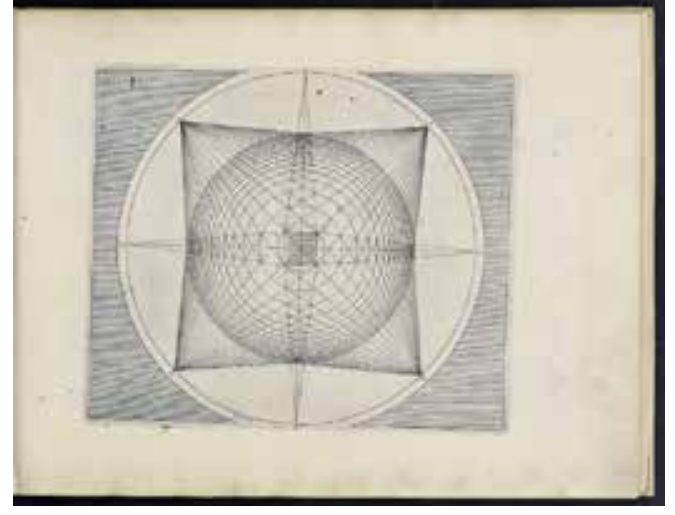

Fig. 19 Hans Vredeman de Vries, Figure 1 in Perspective (Latin edition), 1604, engraving on laid paper, $27 \times 36 \mathrm{~cm}$ (sheet), Getty Research Institute, Los Angeles (artwork in the public domain)

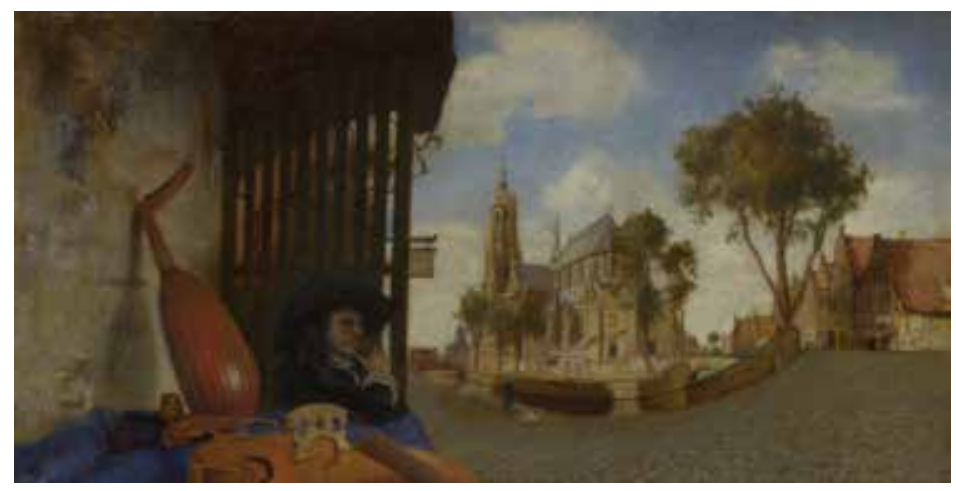

Fig. 20 Carel Fabritius; A View in Delft; 1652; National Gallery, London; NG3714, presented by The Art Fund, 1922; (artwork in the public domain)

The use of an aperture for facilitating an eccentric viewing position is documented in the work of at least one of van Hoogstraten's contemporaries. In 1667 and 1668 Jan van der Heyden painted two views of the Town Hall of Amsterdam (figs. 21-22). Though the points of view are very similar in both, the perspectives are formulated differently. One is fairly straightforward linear perspective, while the other is projected such that the Town Hall becomes distorted toward the top and left of the painting, and the cupola appears distended. A letter to the purchaser of the painting-no less a figure than Cosimo de' Medici-has survived, describing its prescribed viewing: "One must look at it from one exact point, through a metal instrument attached to the frame." ${ }^{31}$ The casting of viewer as "eccentric observer" not only corrects the distortion of the cupola but also more effectively envelops the viewer in the space of the Dam Square. The Town 


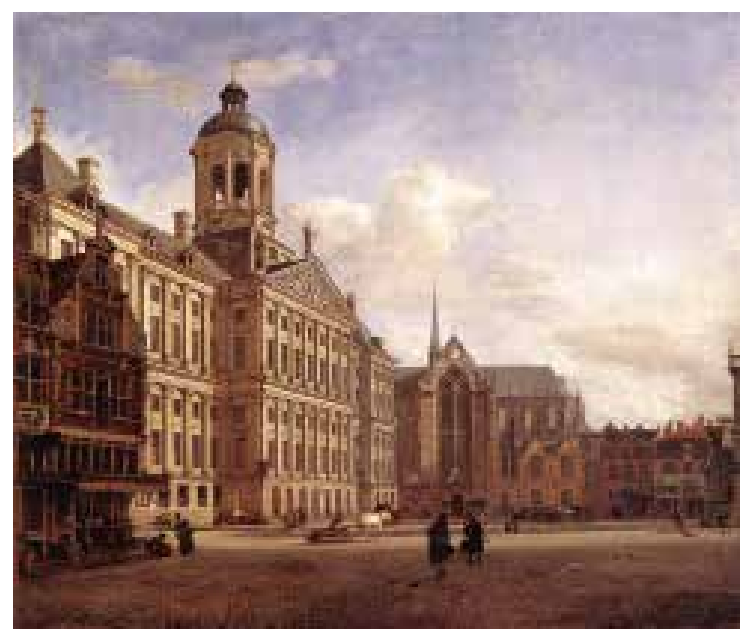

Fig. 21 Jan van der Heyden, Amsterdam, Dam Square with the Town Hall and the Nieuwe Kerk, 1668, oil on canvas, 73 ×86 cm, Musée du Louvre, Paris, INV1337 (artwork in the public domain)

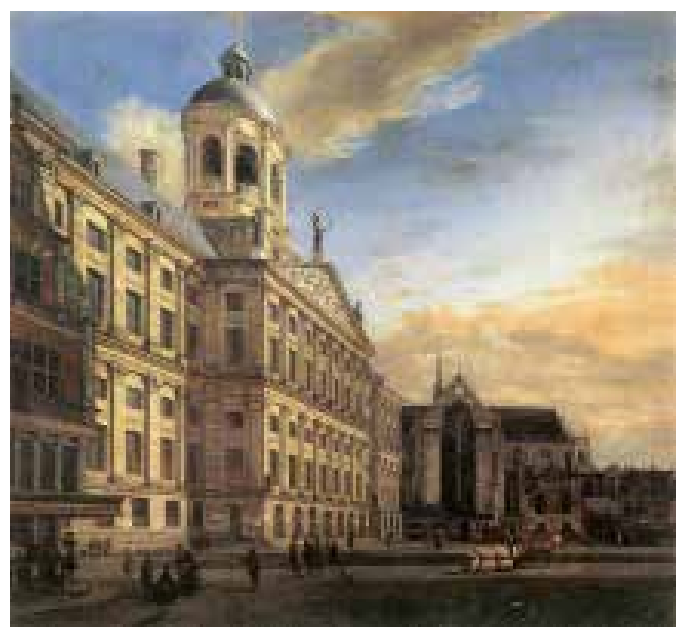

Fig. 22 Jan van der Heyden, View of the Town Hall of Amsterdam with the Dam, 1667, oil on canvas, $85 \times 92 \mathrm{~cm}$, Galleria degli Uffizi, Florence, Inv. 1890: 1211 (artwork in the public domain)

Hall, seen from below, towers over the viewer and expands around them to the left. One has the sense that he or she is at street level alongside the previously diminutive figures, who now appear much larger to the repositioned viewer. ${ }^{32}$ Such a precedent lends credence to the possibility of a corrective apparatus mounted atop van Hoogstraten's box, be it a lens or an aperture. ${ }^{3}$

There is a third method by which the image could be corrected, which is perhaps the least likely. A convex mirror mounted above the dark brown strip could function much like the lens, but it has similar problems of distortion, among other disadvantages. ${ }^{34}$ Unlike the lens, the mirror would need to be viewed from the opposite end of the box. The image would be reduced in size in the mirror, and the required viewing distance compounds the problem, making details difficult to see (figs. 23-24). Still, cylindrical mirrors were often used to correct anamorphoses, discussed in perspective treatises, and mentioned by van Hoogstraten in Book Seven of the Inleyding. ${ }^{35}$ Though less effective than the lens and peephole, it corrects the distortions of the anamorphosis adequately.

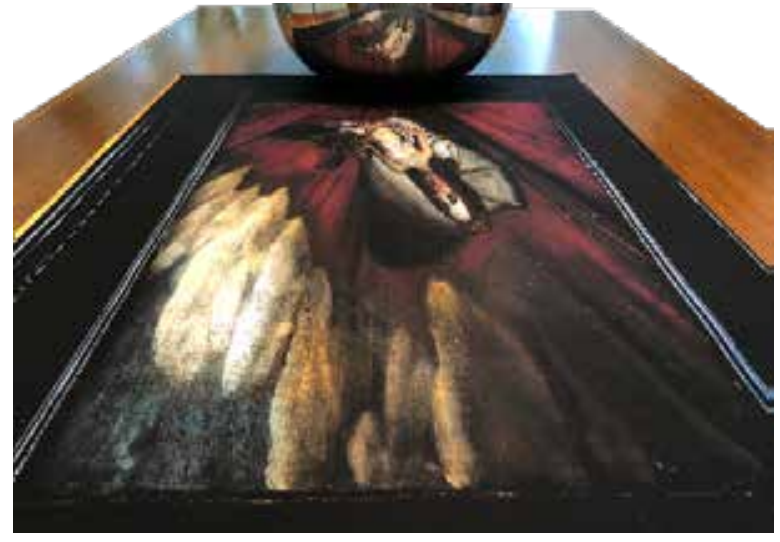

Fig. 23 Full-scale facsimile of fig. 7 as reflected in a convex mirror

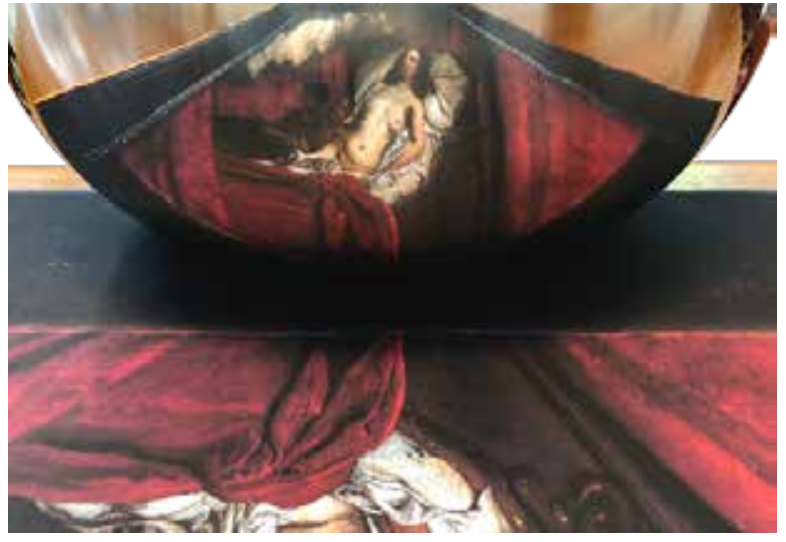

Fig. 24 Full-scale facsimile of fig. 7 as reflected in a convex mirror (closeup; a view that would be difficult to achieve with the actual box) 
It is also possible that the lens, aperture, and/or mirror were removeable components that could be mounted interchangeably, merely set atop the brown strip. The components could have even been handheld, requiring viewers to play with the positioning to "solve" the image as if it were a sort of visual puzzle (fig. 25). This falls in line with Sven Duprés characterization of ad hoc optical demonstrations of the sixteenth and seventeenth centuries in which "various and different optical design elements (lenses, mirrors, apertures) were brought together and assembled in diverse ways" in order to produce different optical effects. ${ }^{36}$ Were this the case with the lid of van Hoogstraten's box, it would demonstrate more explicitly the interchangeability of the eye (via the aperture) and the lens, while also putting into relief differences between the various viewing experiences. It would thus create a more participatory experience that forces the viewer to study and investigate the optical principles at play and to consider their own relative position within this system of seeing.

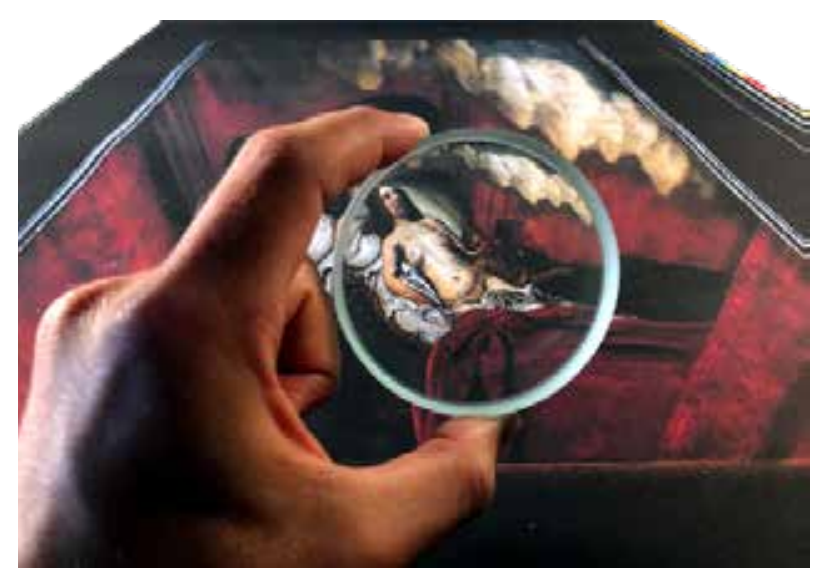

Fig. 25 Full-scale facsimile of fig. 7 as viewed through a $7.5 \mathrm{~cm}$ diameter biconcave lens with $20 \mathrm{~cm}$ focal length, held about $9 \mathrm{~cm}$ above the image, angled slightly downward

The present study has heretofore dealt largely with the mechanics of the London box's lid, but the mediated viewing of the anamorphosis also has implications vis-à-vis its subject matter and its place in the larger exterior program. The exterior walls feature allegorical representations of Seneca's three motivations for art: Amoris Causa, Gloriæ Causa, and Lucri Causa (figs. 4-6). Each representation includes an artist with his back to the viewer, working in a dark, ambiguous space filled with billowing gray clouds. There is a progression implied in the images, beginning with Amoris Causa, the side from which the anamorphosis would have been viewed and one of the two sides with peephole views of the interior. The artist on this panel is sketching with red chalk on paper, practicing the art of drawing (teykenkonst), which is the subject of the first book of Van Hoogstraten's Inleyding and the foundation of all other arts. It is the originary art, just as love is the first benefit of art. ${ }^{37}$ Van Hoogstraten (paraphrasing Seneca) explains that a love of art precedes the benefits of earnings and honor, and this face of the box is thus the logical starting point. $^{38}$

22 A putto directs the draughtsman, gesturing both toward his subject and to the peephole at this end of the box. Behind him, a small opening in the clouds reveals a small sliver of landscape, the coloring of which suggests dawn. The artist's subject is a combination of Natura and the muse Urania. ${ }^{39}$ Natura is identifiable by her many breasts, and she is a suitable subject for the young 
pupil who, van Hoogstraten advises, should have not only a love of art but also a love of investigating and portraying "nature in all her peculiarities." ${ }^{40}$ In a clever reversal, van Hoogstraten shows an artist working naar het leven (after nature) in a manner paradoxically uit den geest (from the imagination or spirit). ${ }^{41}$ Urania is the muse of the final book of the Inleyding concerning the rewards of the artist, and the book's title plate shows her surrounded by objects and scenes that suggest the wealth and praise that await the artist (fig. 26). ${ }^{42}$ On the box, however, Urania is identifiable only by the globe and stars above her head, with the expected rewards reserved for the other faces of the box. ${ }^{43}$

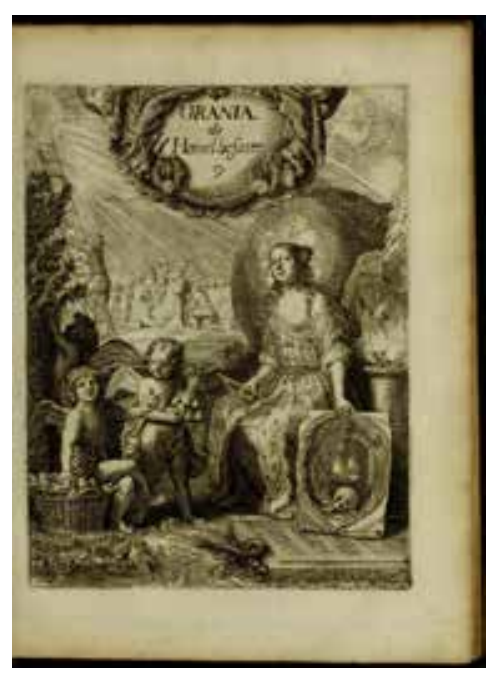

Fig. 26 Samuel van Hoogstraten, Urania, 1678, etching on laid paper, $16.3 \times 12.4 \mathrm{~cm}$ (plate), Sterling and Francine Clark Art Institute Library, Williamstown, ND653 H655.8i 1678 (artwork in the public domain)

In Glorice Causa, on the opposite end of the box, a putto bestows a gold chain and crown of laurels upon the artist, granting some of the rewards promised by Urania. The putto's gesture, again, points toward the peephole. The painter is more ornately dressed than his counterparts elsewhere on the box, probably denoting a courtly appointment. ${ }^{44}$ His painting appears in its early stages, and it is unclear whether he is in the process of painting or underdrawing. ${ }^{45}$ As before, the clouds open up beside him to reveal a landscape, but here much more is visible, and the light is no longer crepuscular in nature.

24 In Lucri Causa, the largest panel of the three, a round-faced, wingless putto reclines against a cornucopia that he holds as riches spill from its opening. The figure is a young Plutus, god of riches and wealth. ${ }^{46} \mathrm{He}$ looks out at the viewer holding a scepter and wearing a crown, markers of his prosperity. The painter, no longer directed by putti, is placed further from the viewer, with his back turned. His hands are concealed; no brush or maulstick is visible; and no model sits before him. The completed image of a noblewoman on his panel may indicate that he is, in fact, finished painting. ${ }^{47}$ The clouds behind him open up to reveal still more landscape and a bright blue sky.

The box's exterior implies a progression from love, to glory, and then to wealth. This order is the same as given by Seneca and initially repeated by van Hoogstraten in his Inleyding, although he later switches wealth and glory when discussing each in more depth. ${ }^{48}$ The panels illustrate in sequence an artist aided by putti to one who is independent, from drawing to painting to finished work, and from concealment to revelation of the landscape, which likewise proceeds from dawn to day. ${ }^{49}$ There may even be a progression in the artists' ages, if one can judge by the draughts- 
man's unkempt hair and the other artists' increasingly straight, more groomed tresses. ${ }^{50}$ Like van Hoogstraten's Inleyding, the exterior program of the box offers a path for the artist to follow, and just as in the Inleyding, he begins with the basics of drawing and instruction and concludes with fortunes, fame, and wealth.

26 The lid's painting is largely independent from the program of the exterior walls. Ignoring the unique anamorphic projection of the image, there is also no painter depicted, and the space is a recognizable physical one: a bedchamber. While it, too, includes clouds above the bed and a putto figure, the putto's skin is of a more golden tonality, his wings red rather than white, and his face more boyish and proportions more delicate than the robust putti of the other panels. His bow further distinguishes him specifically as Cupid. ${ }^{51}$ Cupid gives clues to the identity of the nude female figure, who has alternatively been called Venus, Erato, and Danaë. Venus is the most common attribution, but her associations are rather general; and in any case, it is not unlikely that van Hoogstraten intended his figure to have multiple associations, as does the Urania/Natura figure on the side of the box.

27 Herman Colenbrander and Jan Blanc put forth an identification as Danaë, citing the upward, expectant gazes of the figures and the coins spilling from the cornucopia on the side of the box. ${ }^{52}$ The story of Danaë is apropos in that, as Karel van Mander tells us, "[Acrisius] had a secret chamber constructed from copper underground beneath his room, in which he shut away [Danaë] ... so that she could not be impregnated by anyone." ${ }^{33}$ What's more, once Danaë was impregnated by Zeus, her father "enclosed the mother and child ... in a wooden chest, shut and well-sealed." ${ }^{54}$ The resonances of the perspective box and its lid with an enclosed wooden box and a chamber hidden from view are difficult to ignore. If it is indeed Danaë, the exaggerated point of view places the viewer in the position of Zeus, in the form of a shower of gold about to impregnate Danaë: note the conspicuously exposed lower abdomen. The perspective from above, which is more pronounced when viewed through an aperture, does indeed give the impression that one is looking down into a sealed-off underground chamber, and even down into the box itself. While Acrisius hid Danaë from view by enclosing her in an underground chamber and then in a wooden box, van Hoogstraten has hidden her perspectivally, only to be revealed by those with the knowhow to visually enter her enclosure.

Brusati offers another reading of the figure as Erato. She cites van Hoogstraten's Fourth Book of the Inleyding, in which he explains that Venus sent Cupid to be eternally joined with Erato, whom he later calls a "Venus among the Muses." 55 This reading is compelling in light of a passage in the Inleyding in which the artist addresses Erato directly, asking her to "open to us the inner chambers, where the ladies in waiting prepare to dance, or sigh out of love in their elegant bedchambers." ${ }^{56}$ Erato, as the fourth of the nine muses that structure each book of the Inleyding, acts as a guide on the path of the enlightened painter, a path imagined as a structure of rooms and chambers into which the muse gives access. In the context of the box's lid, Erato draws the viewer into her chamber with both erotic and perspectival enticement, and her role as the Minnedichster, or love poetess, links her to Amoris Causa.

In fact, all three possible identifications hold amorous connotations linking them with Amoris Causa on the exterior. But besides love as a motivation for the artist, the erotic positioning of the 
figure in a bedchamber and the experience of viewing her from above through a peephole or lens further serve to arouse desirous feelings in a presumably heterosexual male viewer. But this was hardly mere smut; such an arousal relates to van Hoogstraten's theories on the passions and bridges the sensory world of the purely visual with the interior world of the viewer. Van Hoogstratenfollowing Franciscus Junius-argued that great works of art ought not only to be beautiful but should also "have a certain moving-ness in them, which has power over its viewers." ${ }^{57}$ In invoking this capacity for inciting movement (beweeglijkheyt), van Hoogstraten speaks of stirring both emotional and physical reactions, as physical movements were seen as an analogue to internal feelings. ${ }^{58}$ The box's moving power over its viewer is compounded by the fact that it demands a literal movement of the body in order to accommodate the strictures of its viewing apparatuses. Once pulled into the reclining nude's crimson chamber, the viewer's inner passions were likewise stoked. ${ }^{59}$

The clouds above the Venus figure lend the whole scene an air of ephemerality; it is always revealing itself or in danger of receding back into clouds. Indeed, the image only coheres when seen through the corrective apparatus of a lens or aperture, and it dissolves back into streaks of color on a flat surface once the viewer leaves the prescribed viewpoint. On the exterior panels, with each progression of the artist and his artwork, the clouds part to reveal more of an increasingly illuminated landscape. The artist's environment on the exterior walls is not a heavenly realm filled with light, but rather an obfuscated space composed of clouds and umbrae. The painter occupies an obscure and invisible world, which he reveals through his art. The culmination of this revelation is atop the box, where the obfuscation lifts to reveal the bedchamber of the Venus figure, who arouses the inner passions of the viewer.

31 The box as a whole is then not only about deception but also about revelation: the revelation of seeing itself, or of seeing clearly for the first time. Van Hoogstraten's trompe l'oeil paintings are ostensibly meant to be seen as something other than paintings-a cabinet door or a letter rackbefore the realization of the painted surface. This tradition was established in antiquity with Pliny's story of a contest between Zeuxis and Parrhasius, in which Zeuxis created a painting of grapes so convincing as to deceive birds, and in response Parrhasius painted a curtain so lifelike that it fooled Zeuxis. Van Hoogstraten, in addition to retelling the story in his Inleyding, had his own sort of Zeuxis tale, wherein his paintings fooled the Emperor Ferdinand III, leading to his decoration by the Emperor. ${ }^{60}$ Such trompe loeil paintings start with a pretext of deception that gives way to the realization of their fiction upon closer inspection, and therein lies their amusement. Conversely, van Hoogstraten's box begins with its identity fixed as an object composed of painted surfaces that then gives way to an illusion, thus foregrounding the deception itself. One sees this inner bedchamber (or the Dutch interior inside the box) in spite of what one knows is merely patches of paint on a wooden panel. In the exterior panels, the revelation of the landscape in concert with the progression of the artist illustrates the revelatory power of the artist's work, a claim reiterated by the putti who gesture toward the peepholes on either end of the box. The young Plutus, too, gestures with his scepter, pointing upward toward the lid of the box, where the reclining Venus/Danaë/Erato awaits viewers in her perspectivally hidden bedchamber.

In a self-portrait print at the beginning of the Inleyding, Van Hoogstraten presents himself seated in a chair in a room filled with swirling clouds (fig. 27). Beside him is a statue of Atlas, carrying 
an orb labeled the "Visible World." Clouds rise behind him and shroud a second, barely perceptible orb: the "Invisible World." ${ }^{61}$ Van Hoogstraten's naming of Visible and Invisible Worlds in his Inleyding and self-portrait posits that the artist claims access to both, placing him in the privileged position of a preternatural medium, a sort of necromancer endowed with vision and knowledge beyond the visible world and the unique ability to render that knowledge through painting. In the title plate of Book Seven of the Inleyding - concerning light, shadow and perspective-the muse Melpomene demonstrates a similar knowledge of the Invisible World (fig. 28). Crowned with a halo of eyes, she holds a burning lens with which she concentrates the light of the world forward in the form of a cone of light, echoing the cones found in the perspectival and optical diagrams of Vredeman, Descartes, and Kepler (fig. 29). Melpomene-as Van Hoogstraten's muse of light, shadow, and perspective-takes her lens and "creates pleasure in that which diminishes or magnifies, darkens or illuminates, emerges or gets undone." ${ }^{\prime 2}$ In his treatise, self-portrait, and especially in his perspective box, Van Hoogstraten lays claim to these powers of the demigod Melpomene, using his representational prowess to reconstitute an obscure and inaccessible world into painted allegories and interiors. He shares this power with his audience not only by presenting them with the anamorphic image revealed through a lens, aperture, and/or mirror-demonstrating for them the mechanics of vision itself-but also by inviting his viewers into shrouded and hidden chambers, leading to a knowledge that will unveil the visible world.

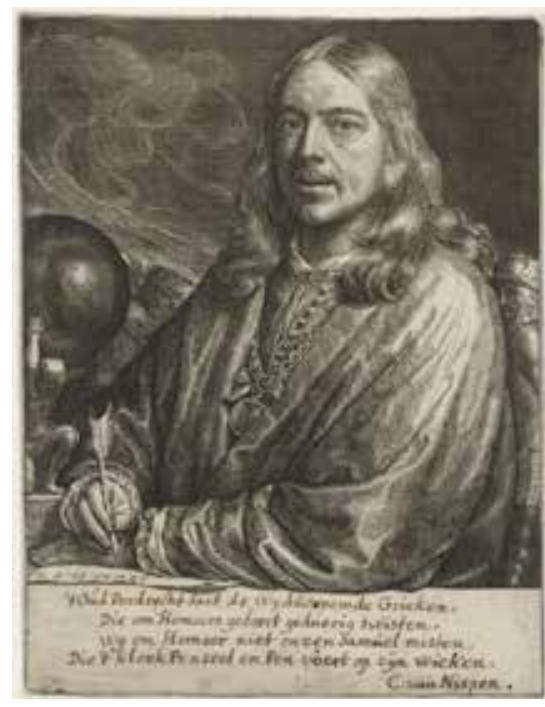

Fig. 27 Samuel van Hoogstraten, Author Self-Portrait, 1677, etching on laid paper with pen and ink inscription, state i/iii, $16.2 \times 12.3 \mathrm{~cm}$ (plate), Rijksmuseum, Amsterdam, RP-P-OB-12.783 (Photo: Rijksmuseum, Amsterdam; artwork in the public domain)

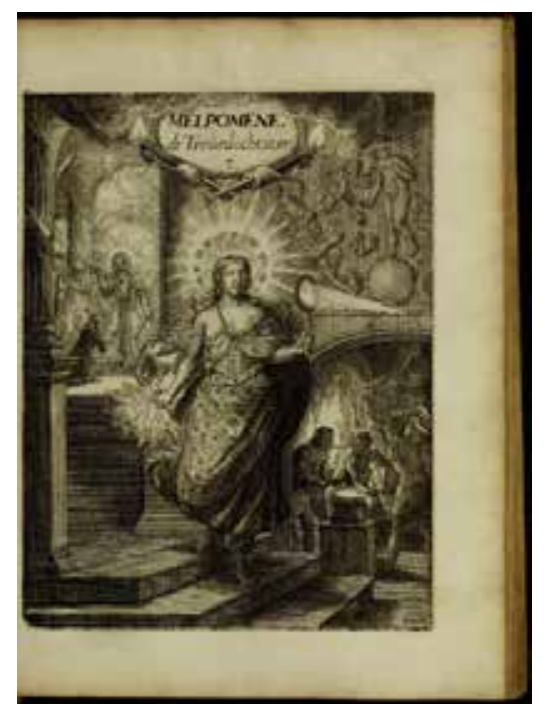

Fig. 28 Samuel van Hoogstraten, Melpomene, 1678 , etching on laid paper, $16.2 \times 12.4 \mathrm{~cm}$ (plate), Sterling and Francine Clark Art Institute Library, Williamstown, ND653 H655.8i 1678 (artwork in the public domain)

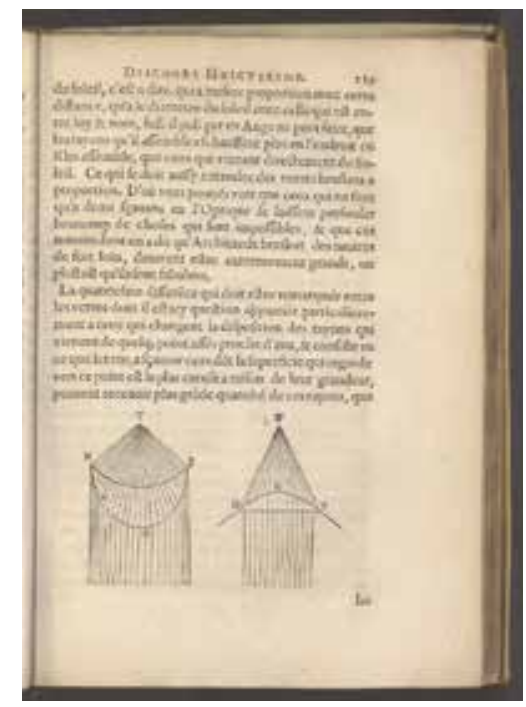

Fig. 29 Page from Descartes's Discours de la methode, 1637, woodcut and letterpress on laid paper, $15 \times 21 \mathrm{~cm}$, Library of Congress, Rare Book and Special Collections Division, Washington, Q155.D43 (book in the public domain) 


\section{Acknowledgements}

I am grateful first and foremost to Celeste Brusati for advising me throughout the development of this article, which began as a term paper for her class in my first semester of the PhD program at the University of Michigan. I wish to dedicate this article to her on the occasion of her retirement. I would also like to thank conservators Kristina Mandy and Claire Shepherd for accommodating my visits to access curatorial files and view the box in storage at the National Gallery. Lastly, I owe thanks to Lydia Aikenhead, Sven Dupré, Alison Kettering, and two anonymous peer reviewers for offering their thoughts and comments.

Jun Nakamura is a PhD candidate in the History of Art at the University of Michigan and the 2018-20 Kress Institutional Fellow at Leiden University. He works on seventeenth-century Dutch topics and the history of printmaking, with further interests in early modern science and transoceanic exchange. His dissertation explores rhetorics of prints and printedness by looking at how certain styles of engraving were established, manipulated, appropriated, and subverted in the Netherlands in the long seventeenth century.

junn@umich.edu

\section{List of Illustrations}

Fig. 1 Samuel van Hoogstraten, A Peepshow with Views of the Interior of a Dutch House, 1655-60, oil and egg on wood, $58 \times 88 \times 60.5 \mathrm{~cm}$, National Gallery, London, NG3832, presented by Sir Robert and Lady Witt through the National Art Collections Fund, 1924 (licensed under Creative Commons)

Fig. 2 Samuel van Hoogstraten, A Peepshow with Views of the Interior of a Dutch House, oblique view (ㄷ The National Gallery, London)

Fig. 3 Samuel van Hoogstraten, A Peepshow with Views of the Interior of a Dutch House, interior layout (ㄷ The National Gallery, London)

Fig. 4 Samuel van Hoogstraten, Amoris Causa, side panel of A Peepshow with Views of the Interior of a Dutch House, 58 x $60.5 \mathrm{~cm}$ (ㅇ The National Gallery, London)

Fig. 5 Samuel van Hoogstraten, Gloriae Causa, side panel of A Peepshow with Views of the Interior of a Dutch House, 58 x $60.5 \mathrm{~cm}$ (๑) The National Gallery, London)

Fig. 6 Samuel van Hoogstraten, Lucri Causa, side panel of A Peepshow with Views of the Interior of a Dutch House, 58 x $88 \mathrm{~cm}$ (ㄷ The National Gallery, London)

Fig. 7 Samuel van Hoogstraten, Venus/Danaë/Erato and Cupid, top panel of A Peepshow with 
Views of the Interior of a Dutch House, $88 \times 60.5 \mathrm{~cm}$ (ㄷ The National Gallery, London)

Fig. 8 Fig. 7 seen from viewpoint proposed by previous scholarship

Fig. 9 Fig. 7 overlaid with lines drawn from vertical compositional elements

Fig. 10 Full-scale facsimile of fig. 7 with a $7.5 \mathrm{~cm}$ diameter biconcave lens with $20 \mathrm{~cm}$ focal length, mounted $9.5 \mathrm{~cm}$ above the image, angled slightly downward

Fig. 11 Full-scale facsimile of fig. 7 with a $7.5 \mathrm{~cm}$ diameter biconcave lens with $20 \mathrm{~cm}$ focal length, mounted $9.5 \mathrm{~cm}$ above the image, angled slightly downward

Fig. 12 Full-scale facsimile of fig. 7 as viewed through a $7.5 \mathrm{~cm}$ diameter biconcave lens with 20 $\mathrm{cm}$ focal length, placed $9.5 \mathrm{~cm}$ above the image, angled slightly downward

Fig. 13 Full-scale facsimile of fig. 7 as viewed through a $7.5 \mathrm{~cm}$ diameter biconcave lens with 20 $\mathrm{cm}$ focal length, placed $9.5 \mathrm{~cm}$ above the image, angled slightly downward

Fig. 14 Mock-up of an aperture/peephole mounted atop a full-scale facsimile of fig. 7

Fig. 15 Mock-up of an aperture/peephole mounted atop a full-scale facsimile of fig. 7

Fig. 16 Full-scale facsimile of fig. 7 as seen through an aperture/peephole of $2.5 \mathrm{~cm}$ diameter, placed $9.8 \mathrm{~cm}$ above the image

Fig. 17 Full-scale facsimile of fig. 7 as seen through an aperture/peephole of $2.5 \mathrm{~cm}$ diameter, placed $9.8 \mathrm{~cm}$ above the image

Fig. 18 Full-scale facsimile of fig. 7 as seen through an aperture/peephole of $2.5 \mathrm{~cm}$ diameter, placed $9.8 \mathrm{~cm}$ above the image

Fig. 19 Hans Vredeman de Vries, Figure 1 in Perspective (Latin edition), 1604, engraving on laid paper, 27 x $36 \mathrm{~cm}$ (sheet), Getty Research Institute, Los Angeles (artwork in the public domain)

Fig. 20 Carel Fabritius; A View in Delft; 1652; National Gallery, London; NG3714, presented by The Art Fund, 1922; (artwork in the public domain)

Fig. 21 Jan van der Heyden, Amsterdam, Dam Square with the Town Hall and the Nieuwe Kerk, 1668, oil on canvas, $73 \times 86 \mathrm{~cm}$, Musée du Louvre, Paris, INV1337 (artwork in the public domain)

Fig. 22 Jan van der Heyden, View of the Town Hall of Amsterdam with the Dam, 1667, oil on canvas, 85 x $92 \mathrm{~cm}$, Galleria degli Uffizi, Florence, Inv. 1890: 1211 (artwork in the public domain)

Fig. 23 Full-scale facsimile of fig. 7 as reflected in a convex mirror 
Fig. 24 Full-scale facsimile of fig. 7 as reflected in a convex mirror (close-up; a view that would be difficult to achieve with the actual box)

Fig. 25 Full-scale facsimile of fig. 7 as viewed through a $7.5 \mathrm{~cm}$ diameter biconcave lens with 20 $\mathrm{cm}$ focal length, held about $9 \mathrm{~cm}$ above the image, angled slightly downward

Fig. 26 Samuel van Hoogstraten, Urania, 1678, etching on laid paper, $16.3 \times 12.4 \mathrm{~cm}$ (plate), Sterling and Francine Clark Art Institute Library, Williamstown, ND653 H655.8i 1678 (artwork in the public domain)

Fig. 27 Samuel van Hoogstraten, Author Self-Portrait, 1677, etching on laid paper with pen and ink inscription, state i/iii, 16.2 x $12.3 \mathrm{~cm}$ (plate), Rijksmuseum, Amsterdam, RP-P-OB-12.783 (Photo: Rijksmuseum, Amsterdam; artwork in the public domain)

Fig. 28 Samuel van Hoogstraten, Melpomene, 1678, etching on laid paper, 16.2 x $12.4 \mathrm{~cm}$ (plate), Sterling and Francine Clark Art Institute Library, Williamstown, ND653 H655.8i 1678 (artwork in the public domain)

Fig. 29 Page from Descartes's Discours de la methode, 1637, woodcut and letterpress on laid paper, 15 x $21 \mathrm{~cm}$, Library of Congress, Rare Book and Special Collections Division, Washington, Q155. D43 (book in the public domain)

\section{Bibliography}

Alpers, Svetlana. The Art of Describing: Dutch Art in the Seventeenth Century. Chicago: University of Chicago Press, 1983. https://doi.org/10.5117/ivn2012.0.boer

Blanc, Jan. Peindre et penser la peinture au XVIIe siècle: la théorie de l'art de Samuel van Hoogstraten. Bern: Peter Lang, 2008. https://doi.org/10.4000/contextes.66

Brière-Misme, Clotilde. "Deux 'boites à perspective' hollandaises du XVIIe siècle." Gazette Des Beaux-Arts 1 (1925): 156-66.

Brown, Christopher, David Bomford, Joyce Plesters, and John Mills. "Samuel van Hoogstraten: Perspective and Painting." National Gallery Technical Bulletin 11 (1987): 60-85.

Brusati, Celeste. Artifice and Illusion: The Art and Writing of Samuel Van Hoogstraten. Chicago: University of Chicago Press, 1995.

- "Capitalizing on the Counterfeit: Trompe L'Oeil Negotiations." In Still-Life Paintings from the Netherlands, 1550-1720, edited by Alan W. Chong and Wouter Kloek, 59-71. Zwolle: Waanders, 1999.

-. "Looking at Samuel van Hoogstraten's Dogs in Perspective." In Liber amicorum Marijke de 
Kinkelder: collegiale bijdragen over landschappen, marines en architectuur, edited by Charles Dumas, Jan Kosten, Eric Jan Sluijter, and Nicolette C. Sluijter-Seijffert, 49-68. Zwolle: Waanders, 2013.

-. "Paradoxical Passages: The Work of Framing in the Art of Samuel van Hoogstraten." In The Universal Art of Samuel Van Hoogstraten (1627-1678): Painter, Writer, and Courtier, edited by Thijs Weststeijn, 53-75. Amsterdam: Amsterdam University Press, 2013. https://doi. org/10.1515/9789048518593-004

—. "Perspectives in Flux: Viewing Dutch Pictures in Real Time." Art History 35, no. 5 (2012): 909-33. https://doi.org/10.1111/j.1467-8365.2012.00930.x

Colenbrander, Herman. "A Pledge of Marital Domestic Bliss: Samuel van Hoogstraten's Perspective Box in the National Gallery, London." In The Universal Art of Samuel Van Hoogstraten (16271678): Painter, Writer, and Courtier, edited by Thijs Weststeijn, 138-59. Amsterdam: Amsterdam University Press, 2013. https://doi.org/10.1515/9789048518593-008

Collins, Daniel L. "Anamorphosis and the Eccentric Observer: Inverted Perspective and Construction of the Gaze." Leonardo 25, no. 1 (1992): 73-82. https://doi.org/10.2307/1575625

Crombie, Alistair C., trans. "Kepler: De Modo Visionis." In L'aventure de la science: Melanges Alexander Koyré, 1:135-72. Paris: Hermann, 1964.

Czech, Hans-Jörg. Im Geleit der Musen: Studien zu Samuel van Hoogstratens Malereitraktat Inleyding tot de hooge schoole der schilderkonst: anders de zichtbaere werelt. Münster: Waxmann, 2002.

Della Porta, Giambattista. Natural Magick by John Baptista Porta, a Neapolitane; in Twenty Books ... Wherein Are Set Forth All the Riches and Delights of the Natural Sciences. London: Printed for Thomas Young and Samuel Speed, 1658.

Descartes, René. Discours de la méthode pour bien conduire sa raison et chercher la vérité dans les sciences, plus la dioptrique, les météores et la géométrie qui sont des essais de cette méthode. Leiden: Jan Maire, 1637.

Dupré, Sven. "How-To Optics." In Perspective as Practice: Renaissance Cultures of Optics, edited by Sven Dupré, 279-300. Turnhout: Brepols, 2019. https://doi.org/10.1484/m.techne.5.117730

-. "Inside the Camera Obscura: Kepler's Experiment and Theory of Optical Imagery." Early Science and Medicine 13 (2008): 219-44.

—. "Playing with Images in a Dark Room: Kepler's Ludi inside the Camera Obscura." In Inside the Camera Obscura: Optics and Art Under the Spell of the Projected Image, edited by Wolfgang Lefèvre, 59-74. Berlin: Max-Planck-Institut für Wissenschaftsgeschichte, 2007.

Fowler, Caroline O. “Consonant and dissonant perspectives: Carel Fabritius' A View in Delft 
(1652)." In “The Most Noble of the Senses": Anamorphosis, Trompe-L'Oeil, and Other Optical Illusions in Early Modern Art, edited by Lilian H. Zirpolo, 49-66. Ramsey, NJ: Zephyrus Scholarly Publications, 2016.

Houbraken, Arnold. De Groote Schouburgh Der Nederlantsche Konstschilders En Schilderessen. 's Gravenhage: J. Swart, C. Boucquet, en M. Gaillard, 1753.

Kepler, Johannes. Optics: Paralipomena to Witelo \& Optical Part of Astronomy, translated by William H. Donahue. Santa Fe, NM: Green Lion Press, 2000.

Koslow, Susan. "De Wonderlijke Perspectyfkas: An Aspect of Seventeenth Century Dutch Painting." Oud Holland 82, no. 1 (1967): 35-56. https://doi.org/10.1163/187501767x00206

Liedtke, Walter A. “The 'View in Delft' by Carel Fabritius." The Burlington Magazine 118, no. 875 (1976): 61-73.

Liedtke, Walter A., Michiel Plomp, and Axel Rüger. Vermeer and the Delft School. New York: Metropolitan Museum of Art, 2001.

National Gallery Dossier NG3832, The National Gallery, London.

Oczko, Piotr. "Miotły i zamtuzy: jeszcze raz o 'znaczeniach ukrytych' w sztuce holenderskiej XVII w.: (malarstwo rodzajowe i kasety perspektywiczne).” Biuletyn Historii Sztuki 75/1 (2013): 5-35.

Ripa, Cesare, Dirck Pers, and Giovanni Zaratino Castellini. Iconologia, of Uytbeeldingen Des Verstands ... Met. . . De Uytnemende Verbeteringe Van G. Zaratino Castellini . . Amsterdam: D. P. Pers, 1644.

Spencer, Justina. "Illusion as Ingenuity: Dutch Perspective Boxes in the Royal Danish Kunstkammer's 'Perspective Chamber." Journal of the History of Collections 30/2 (2018): 187-201.

Stauffer, Marie Theres. "Mirror Art: Early Modern Catoptric Devices in Books, Collections, and Demonstrations." In “The Most Noble of the Senses”: Anamorphosis, Trompe-L'Oeil, and Other Optical Illusions in Early Modern Art, edited by Lilian H. Zirpolo, 67-86. Ramsey, NJ: Zephyrus Scholarly Publications, 2016.

Swan, Claudia. "Ad Vivum, Naer Het Leven, from the Life: Defining a Mode of Representation." Word \& Image 11/4 (1995): 353-72. https://doi.org/10.1080/02666286.1995.10435926

Sutton, Peter C. and Jonathan Bikker. Jan Van Der Heyden (1637-1712). New Haven: Yale University Press, 2006.

Van Hoogstraten, Samuel. Inleyding tot de hooge schoole der schilderkonst: anders de zichtbaere werelt. .. . Ten hoogsten noodzakelijk, tot onderwijs. Rotterdam: Fransois van Hoogstraeten, 1678. 
Van Mander, Karel. Wtlegghingh op den Metamorphosis Pub. Ouidij Nasonis . . Haarlem: Paschier van Westbusch, 1604. https://www.dbnl.org/tekst/mand001schi01 01

Vredeman de Vries, Hans. Perspective: Dat is, de hooch-gheroemde conste eens schijnende in oft door-siende ooghen-ghesichtes punt . . Leiden: Hendrick Hondius, 1604.

Weststeijn, Thijs. "Between Mind and Body: Painting the Inner Movements According to Samuel van Hoogstraten and Franciscus Junius.” Nederlands Kunsthistorisch Jaarboek 60 (2010): 261-81. https://doi.org/10.1163/22145966-90000762

- The Visible World: Samuel Van Hoogstraten's Art Theory and the Legitimation of Painting in the Dutch Golden Age, translated by Beverley Jackson and Lynne Richards. Amsterdam: Amsterdam University Press, 2008. https://doi.org/10.5117/9789089640277

Wheelock, Arthur K. "Carel Fabritius: Perspective and Optics in Delft." Nederlands Kunsthistorisch Jaarboek 24 (1973): 63-83. https://doi.org/10.1163/22145966-90000684

Woodall, Joanna. "Love Is in the Air: Amor As Motivation and Message in Seventeenth-Century Netherlandish Painting." Art History 19 (1996): 208-246. https://doi. org/10.1111/j.1467-8365.1996.tb00664.x

Zuidervaart, Huib J. and Marlise Rijks. “Most rare workmen': Optical practitioners in early seventeenth-century Delft." The British Journal for the History of Science 48, no. 1 (2015): 53-85. HTTPS://DOI.ORG/10.1017/S0007087414000181

${ }^{1}$ National Gallery, London (Inv. NG3832); Detroit Institute of Arts (Acc. 35.101); Bredius Museum (Inv. 217-1946, Cat. 57); Staatsmuseum voor Kunst, Copenhagen (Inv. DEP602); Nationalmuseet Copenhagen (two boxes, on view in gallery 126). Also called peepboxes, all six are described in Susan Koslow, "De Wonderlijke Perspectyfkas: An Aspect of Seventeenth Century Dutch Painting," Oud Holland 82, no. 1/4 (1967): 35-56.

${ }^{2}$ Originally, this was probably covered with translucent paper to let in a diffused light. Christopher Brown, David Bomford, Joyce Plesters, and John Mills, "Samuel van Hoogstraten: Perspective and Painting," National Gallery Technical Bulletin 11 (1987): 63.

${ }^{3}$ Seneca, De Beneficiis 2.33; Joanna Woodall discusses these paintings and the privileged position van Hoogstraten affords Love in "Love is in the Air: Amor As Motivation and Message in Seventeenth-Century Netherlandish Painting," Art History 19 (1996): 208-46.

${ }^{4}$ I use the term "corrective" not in the sense that the image has a right and wrong way to view it, but in that it is a sort of puzzle that has a solution, and both the puzzle and its resolution are showcased in the anamorphosis. This thinking is supported by a passage in the Inleyding in which van Hoogstraten describes anamorphoses, saying that through the use of various kinds of mirrors, "mismaekte gedaentens ... haer opregte form kan geeven" ("distorted shapes . . can give their correct forms"; emphasis my own). Samuel van Hoogstraten, Inleyding tot de hooge schoole 
der schilderkonst: anders de zichtbaere werelt. . . Ten hoogsten noodzakelijk, tot onderwijs (Rotterdam: Fransois van Hoogstraeten, 1678), 274. Translations are my own; some of these translations of the Inleyding were done with input from Celeste Brusati and I also consulted Charles Ford's beta translation published on The University College London's website: HTTPS://WWW.UCL. AC.UK/GRONDT.

${ }^{5}$ Celeste Brusati, Artifice and Illusion: The Art and Writing of Samuel Van Hoogstraten (Chicago: University of Chicago Press, 1995), 86, 177-91.

${ }^{6}$ Thijs Weststeijn, The Visible World: Samuel Van Hoogstraten's Art Theory and the Legitimation of Painting in the Dutch Golden Age, tr. Beverley Jackson and Lynne Richards (Amsterdam: Amsterdam University Press, 2008); Brown, Bromford, et al., "Samuel van Hoogstraten: Perspective and Painting," 60-85; Celeste Brusati, "Paradoxical Passages: The Work of Framing in the Art of Samuel van Hoogstraten" in The Universal Art of Samuel Van Hoogstraten (1627-1678): Painter, Writer, and Courtier, ed. Thijs Weststeijn (Amsterdam: Amsterdam University Press, 2013), 53-75; Herman Colenbrander, “A Pledge of Marital Domestic Bliss: Samuel van Hoogstraten's Perspective Box in the National Gallery, London," in The Universal Art of Samuel Van Hoogstraten, 138-59; Woodall, "Love Is in the Air"; Justina Spencer, "Illusion as Ingenuity: Dutch Perspective Boxes in the Royal Danish Kunstkammer's 'Perspective Chamber," Journal of the History of Collections 30/2 (2018) : 187-201.

On the theme of love and marital readings, see Woodall, "Love Is in the Air" and Colenbrander, "A Pledge of Marital Domestic Bliss," respectively; on its interpretation as a brothel, see Piotr Oczko, "Miotły i zamtuzy: jeszcze raz o 'znaczeniach ukrytych' w sztuce holenderskiej XVII w. : (malarstwo rodzajowe i kasety perspektywiczne)," Biuletyn Historii Sztuki 75/1 (2013): 19-26. ${ }^{8}$ Colenbrander, "A Pledge of Marital Domestic Bliss," 148.

${ }^{9}$ Brown, Bomford, et al., "Samuel van Hoogstraten: Perspective and Painting," 68.

${ }^{10}$ Brown, Bomford, et al., "Samuel van Hoogstraten: Perspective and Painting," 68.

${ }^{11}$ The top panel has a split down its center with a small area of loss that had to be filled and repainted. This split lines up well with where a proposed apparatus would have been mounted, and the split could have formed along a hole from the mount; still, the presence of a similar crack in the end panel cautions against drawing such conclusions. David Bomford et. al., "Brief History of Condition and Treatment," "Condition Report (2/24/1984)," and "Treatment Report (6/12/1986)," National Gallery Dossier NG3832, The National Gallery, London; Brown, Bomford, et al., "Samuel van Hoogstraten: Perspective and Painting," 76.

${ }^{12}$ As with the brown strip atop the box, there are two areas within the interior of the box that have been left unresolved because they probably would have been hidden from view when seen through the opposite peepholes. Bomford also posits that a no-longer-extant wooden piece would have hidden each peephole from the line of sight of the opposite peephole. Brown, Bomford, et al., "Samuel van Hoogstraten: Perspective and Painting," 75.

${ }^{13}$ Van Hoogstraten may have known Caspar Kalthof, a lensmaker praised by Christiaan Huygens for his lens grinding forms. They both signed Johan Mulheuser's album amicorum in 1650 and both lived in Dordrecht prior to moving to England. Brusati, Artifice and Illusion, 292-293n101; beyond Kalthof, there were two other lens grinders working in nearby Delft in the 1650s: Evert Harmansz Steenwijck and Johan van der Wyck, the latter having made lenses for Huygens. By 1655, Van der Wyck had also apparently invented some kind of peepbox in which the view alternated between an Italianate mountain landscape with a castle and a seascape populated with ships. For such a project, he likely would have had to collaborate with a painter. Huib J. Zuider- 
vaart and Marlise Rijks, “Most rare workmen': Optical practitioners in early seventeenth-century Delft," The British Journal for the History of Science 48, no. 1 (2015): 16-21.

${ }^{14}$ Magia Naturalis was published in the Netherlands five times between 1644 and 1664, in both Dutch and Latin editions. The English translation I quote here closely follows the Latin edition. Giambattista della Porta, Natural Magick by John Baptista Porta, a Neapolitane; in Twenty Books ... Wherein Are Set Forth All the Riches and Delights of the Natural Sciences (London: Printed for Thomas Young and Samuel Speed, 1658), 369. For a discussion of Kepler, della Porta, and Van Hoogstraten's use of lenses and their relation to seventeenth-century theories of perspective, see Arthur K. Wheelock, "Carel Fabritius: Perspective and Optics in Delft," Nederlands Kunsthistorisch Jaarboek 24 (1973): 69-70.

${ }^{15}$ Van Hoogstraten, Inleyding, 263; See also Celeste Brusati, "Perspectives in Flux: Viewing Dutch Pictures in Real Time," Art History 35, no. 5 (2012): 918.

${ }^{16}$ For the reconstruction I used a biconcave lens $7.5 \mathrm{~cm}$ diameter, $20 \mathrm{~cm}$ focal length. The ideal lens would have a focal length around $15 \mathrm{~cm}$ and could be either plano-concave or biconcave, with a $5-10 \mathrm{~cm}$ diameter.

${ }^{17}$ Della Porta, Natural Magick, 361-370; on Kepler and "images that hang in the air," see Sven Dupré, "Inside the Camera Obscura: Kepler's Experiment and Theory of Optical Imagery," Early Science and Medicine 13 (2008).

${ }^{18}$ Della Porta, Natural Magick, 368-69; della Porta was using a broad definition of "images that float in the air," due to his misunderstanding of differences between the geometric, perceived, and projected (optical) loci of images. Sven Dupré, "Playing with Images in a Dark Room: Kepler's Ludi inside the Camera Obscura," in Inside the Camera Obscura: Optics and Art Under the Spell of the Projected Image, ed. Wolfgang Lefèvre (Berlin: Max-Planck-Institut für Wissenschaftsgeschichte, 2007), 67-69. Similar floating images-also called "flying images" or "projected reflections" - could likewise be achieved through the use of catoptric devices, which were described in the seventeenth century by Athananius Kircher and Gaspar Schott. On these, see Marie Theres Stauffer, "Mirror Art: Early Modern Catoptric Devices in Books, Collections, and Demonstrations," in "The Most Noble of the Senses": Anamorphosis, Trompe-L'Oeil, and Other Optical Illusions in Early Modern Art, ed. Lilian H. Zirpolo (Ramsey, NJ: Zephyrus Scholarly Publications, 2016), 67-86, esp. 80-84.

${ }^{19}$ Kepler and della Porta describe lenses up to a foot wide. Johannes Kepler, Optics: Paralipomena to Witelo \& Optical Part of Astronomy, tr. William H. Donahue (Santa Fe, NM: Green Lion Press, 2000), 194; della Porta, Natural Magick, 379.

${ }^{20}$ René Descartes, Discours de la méthode pour bien conduire sa raison et chercher la vérité dans les sciences, plus la dioptrique, les météores et la géométrie qui sont des essais de cette méthode (Leiden: Jan Maire, 1637), Dioptrique discourses 3-9, esp. 5.

${ }^{21}$ Kepler, Optics, 181.

${ }^{22}$ Svetlana Alpers, The Art of Describing: Dutch Art in the Seventeenth Century (Chicago: University of Chicago Press, 1983), 34-35; Alistair C. Crombie, trans., "Kepler: De Modo Visionis" in L'aventure de la science: Melanges Alexander Koyré, vol. 1 (Paris: Hermann, 1964), 144-5.

23 “[D]ewijl 'er niets lichter bedroogen wort, als het gezigt. Maer ik zegge dat een Schilder, diens werk het is, het gezigt te bedriegen, ook zoo veel kennis van de natuur der dingen moet hebben, dat hy grondig verstaet, waer door het oog bedroogen wort." Van Hoogstraten, Inleyding, 274.

${ }^{24}$ Brusati, Artifice and Illusion, 177.

${ }^{25}$ Daniel L. Collins, "Anamorphosis and the Eccentric Observer: Inverted Perspective and Con- 
struction of the Gaze," Leonardo. 25, no. 1 (1992): 73-74.

26 “[G]elijk gy zien kunt voor een gebouw of Kerk staende, dat niet alleen beyde de einden der mueren, maer ook de Torens van ons afloopen, verkorten en verschieten. Hoe dwaeslijk waer't, dit aldus af te beelden, ten waer u werk, ook van zeer naby gezien wordende, 't zelve nootzakelijk vereischte." Van Hoogstraten, Inleyding, 34.

${ }^{27}$ Hans Vredeman de Vries, Perspective: Dat is, de hooch-gheroemde conste eens schijnende in oft door-siende ooghen-ghesichtes punt... (Leiden: Hendrick Hondius, 1604).

${ }^{28}$ Brusati discusses this image with respect to the interior of the box in Artifice and Illusion, 184-91; see also Alpers, The Art of Describing, 56-58.

${ }^{29}$ Walter A. Liedtke, "The 'View in Delft' by Carel Fabritius," The Burlington Magazine 118, no. 875 (1976): 61-73, esp. 65-69; see also Walter A. Liedtke, Michiel Plomp, and Axel Rüger, Vermeer and the Delft School (New York: Metropolitan Museum of Art, 2001), 114, 250-55, cat. 18. More recently, Caroline Fowler has explored the resolution of "dissonant" perspectives in Fabritius's View in Delft, relating perspectival theory to early modern music theory and the common tool that they shared: string. Fowler, "Consonant and dissonant perspectives: Carel Fabritius' $A$ View in Delft (1652)," in "The Most Noble of the Senses" (see note 18), 49-66, esp. 58-60, 65-66. 30 " $[\mathrm{W}] \mathrm{y}$ met onze oogen rondom ons zien, en desweegen geen rechte linie kan getogen worden, die op alle plaetsen onze oogen eeven na is; maer wel een kromme, als den omtrek van een kring, waer van het middel punt in ons oog is." Van Hoogstraten, Inleyding, 34.

${ }^{31}$ Peter C. Sutton and Jonathan Bikker, Jan Van Der Heyden (1637-1712) (New Haven: Yale University Press, 2006), 122-26; Brusati, "Perspectives in Flux," 925.

${ }^{32}$ Van Hoogstraten remarked that "the wondrous perspective box ... if painted correctly and with skill, shows a finger-length figure as if life-sized" ("de wonderlijke perspectyfkas, die, alsze regt en met kennisse geschildert is, een figuur van een vinger lang als leevensgroot vertoont"). Inleyding, 274-75.

${ }^{33}$ One finds another unusual addition to a Van Hoogstraten painting in his Court of the Hofburg, Vienna (1652), in which a functioning timepiece was embedded into the clock tower. While it is possible that the timepiece was added by someone else, it would have had to have been added before 1737, when it is first noted in an inventory. It has since been replaced by a painted clock. Brusati, Artifice and Illusion, 73, 287n49.

${ }^{34}$ Mathematician Michael A. B. Deakin proposed placing a mirrored arc above the box in a letter sent to the National Gallery in 1981. Though this solution would only correct only some of the distortions while also introducing some of its own, Deacon recognized the need for some kind of mediation for the anamorphosis to be corrected. Then-curator Christopher Brown dismissed the need for any corrective to the box. Michael A. B. Deakin to The National Gallery Director, May 5, 1981, National Gallery Dossier NG3832, The National Gallery, London; Christopher Brown to Mr. Deakin, June 19, 1981, National Gallery Dossier NG3832, The National Gallery, London.

${ }^{35}$ Van Hoogstraten only mentions them in a sort of apophasis, saying that he will skip over explaining how one can correct distorted images in various kinds of mirrors (see note 4). Van Hoogstraten, Inleyding, 274.

${ }^{36}$ Sven Dupré, "How-To Optics," in Perspective as Practice: Renaissance Cultures of Optics, ed. Sven Dupré (Turnhout: Brepols, 2019), 291.

${ }^{37}$ Woodall has a more in-depth discussion of the primacy of love in the artist's motivations.

Woodall, "Love is in the Air," 235-37.

${ }^{38}$ Van Hoogstraten, Inleyding, 345. 
${ }^{39}$ Woodall argues a tertiary identification as Poetry. Woodall, "Love is in the Air," 214.

40 "de natuur in hare eigenschappen." Van Hoogstraten, Inleyding, 11-12.

${ }^{41}$ Woodall asserts that this panel represents an artist working uit den geest on the basis of the allegorical figure, with the panel being representative of history painting. However, her identification of the figure as Natura complicates such a reading, as working after nature or ad naturam is often defined in opposition to working uit den geest. Woodall, "Love is in the Air," 212-14, 228, 236-37n13; ad naturam was itself a concept closely aligned with ad vivum and naar het leven. See Claudia Swan, "Ad Vivum, Naer Het Leven, from the Life: Defining a Mode of Representation," Word \& Image 11/4 (1995): 362-63.

${ }^{42}$ Van Hoogstraten, Inleyding, 325; Brusati, Artifice and Illusion, 252-56; Hans-Jörg Czech, Im Geleit der Musen: Studien zu Samuel van Hoogstratens Malereitraktat Inleyding tot de hooge schoole der schilderkonst: anders de zichtbaere werelt (Münster: Waxmann, 2002), 362-63; Weststeijn, Visible World, 253; Koslow, "Wonderlijke," 45-46.

${ }^{43}$ The celestial globe above the head is also an attribute of Fortune, the subject of the Eighth Book of the Inleyding, but here she lacks her cornucopia or additional attributes that would indicate positive or negative Fortune. The figure is iconographically potent but purposefully ambiguous, suggesting some amalgamation of Urania, Natura, Fortune, and Poetry. Cesare Ripa, Dirck Pers, and Giovanni Zaratino Castellini, Iconologia, of Uytbeeldingen Des Verstands . . . Met. . . De Uytnemende Verbeteringe Van G. Zaratino Castellini ... (Amsterdam: D. P. Pers 1644), 131.

${ }^{44}$ Brusati and others have noted that the bestowal of the gold chain is a reference to van Hoogstraten's own gold chain, given to him by Emperor Ferdinand III. Van Hoogstraten appears to have valued the honors of the court more than courtly patronage itself, and he used his honors as a way to increase the value of his works outside of the courtly context. Brusati, Artifice and Illusion, 54-55; Brusati, "Capitalizing on the Counterfeit: Trompe L'Oeil Negotiations," in Still-Life Paintings from the Netherlands, 1550-1720, ed. Alan W. Chong and Wouter Kloek (Zwolle: Waanders, 1999), 59-71.

${ }^{45}$ A number of light yellow-green daubs of paint are visible at the top right of the picture, which could either suggest a still life of grapes-Zeuxis's grapes must have never been far from van Hoogstraten's mind-or foliage in a landscape. Given Van Hoogstraten's own penchant for trompe l'oeil and his success in attaining glory (and a gold chain) through it, a grape still life reading is tempting. Immediately above and to the right of the painter one can very faintly see wispy white strokes which may have been preparatory for something to be placed in front of him, but they are too faint and sketchy to make any substantial claims.

${ }^{46}$ Koslow, "Wonderlijke," 46.

${ }^{47}$ However, he does seem to be holding what may be a palette. In any case, the painting appears largely finished.

${ }^{48}$ Van Hoogstraten, Inleyding, 345-61; Clotilde Brière-Misme pointed out the relation of the outer panels to these chapters in the Inleyding in "Deux 'boites à perspective' hollandaises du XVIIe siècle," Gazette des Beaux-Arts 1 (1925): 160-61.

${ }^{49}$ Woodall also discusses the primacy of love in the artist's motivations. Woodall, "Love is in the Air," 235-37.

${ }^{50}$ Van Hoogstraten dedicated three pages to the discussion of hair in his Inleyding, but he says nothing about how hair might reflect age or experience; 144-47. Though not discussed by van Hoogstraten, unkempt hair could also signify artistic inspiration.

${ }^{51}$ Joyce Plesters in Brown, Bomford et al., "Samuel van Hoogstraten: Perspective and Painting," 83. ${ }^{52}$ Colenbrander, "A Pledge of Marital Domestic Bliss," 148-49; Jan Blanc, Peindre et penser la peinture 
au XVIIe siècle: la théorie de l'art de Samuel van Hoogstraten (Bern: Peter Lang, 2008), 24-25.

53 "Heeft hy laten maken van koper een heymelijcke Camer onder zijn Sale onder d'aerde, waer in hy zijn Dochter met de Voester liet besluyten ... op datse niet soude van yemandt worden bevrucht." Van Mander notes that some say she was put in a tower. Wtlegghingh op den metamorphosis Pub. Ouidij Nasonis ... (Haarlem: Paschier van Westbusch, 1604), 37v.

${ }^{54}$ Emphasis added. " . . . besloot hy de Moeder met het kindt ... in een houtten kist, dicht en wel besloten," Van Mander, Wtlegghingh op den metamorphosis, 38r.-40v.

${ }^{55}$ Brusati, Artifice and Illusion, 213, 319n64; Van Hoogstraten, Inleyding, 122-23.

56 “ ... open ons de binnekameren, daer de Hofjufferen zich ten dans bereyden, of in haer sierlijke bedkameren van liefde zuchten." Van Hoogstraten, Inleyding, 123; Brusati, Artifice and Illusion, 240.

${ }^{57}$ Thijs Weststeijn, "Between Mind and Body: Painting the Inner Movements According to Samuel van Hoogstraten and Franciscus Junius," Nederlands Kunsthistorisch Jaarboek 60 (2010): 261, 265.

${ }^{58}$ Weststeijn, "Between Mind and Body," 262-63; Weststeijn, Visible World, 182-83.

${ }^{59}$ Van Hoogstraten's chosen word for passion was hartstocht, literally a movement of the heart. Weststeijn, Visible World, 172-73.

${ }^{60}$ Arnold Houbraken, De groote schouburgh der Nederlantsche konstschilders en schilderessen ('s Gravenhage: J. Swart, C. Boucquet, en M. Gaillard, 1753), 2:157-58.

${ }^{61}$ On both orbs the text is truncated and nearly illegible, having been obscured with hatching. On the Invisible World orb, one can only make out "Onzic[htbare] [We]rel[d]." Neither orb is labeled in the preparatory study for the print, in the collection of the Huis van Gijn, Dordrecht, inv. 1641. For more on the self-portrait, see Czech, Im Geleit, 367-75.

62 "Zy schept vermaek in't geen vermindert of vermeert: / Verdonkert en verklaert: ontluikt of raekt aen't zwichten;" Van Hoogstraten, Inleyding, 243; this passage discussed in Celeste Brusati, "Looking at Samuel van Hoogstraten's Dogs in Perspective," in Liber amicorum Marijke de Kinkelder: collegiale bijdragen over landschappen, marines en architectuur, ed. Dumas et al. (Zwolle: Waanders, 2013), 52, 61, 66.

Recommended Citation:

Jun P. Nakamura, "Seeing Outside the Box: Reexamining the Top of Samuel van Hoogstraten's London Perspective Box," Journal of Historians of Netherlandish Art 12:2 (Summer 2020) D01: 10.5092/jhna.12.2.3 